\title{
Inoculum Density-Disease Development Relationship in Verticillium Wilt of Artichoke Caused by Verticillium dahliae
}

\author{
M. Berbegal, Instituto Agroforestal Mediterráneo, Universidad Politécnica de Valencia, Camino de Vera s/n, 46022 \\ Valencia, Spain; A. Ortega, Universidad Miguel Hernández, Escuela Politécnica Superior de Orihuela, Dpto. de \\ Producción Vegetal y Microbiología, Ctra. Beniel km 3.2, 03312 Orihuela, Alicante, Spain; and J. García-Jiménez \\ and J. Armengol, Instituto Agroforestal Mediterráneo, Universidad Politécnica de Valencia, Spain
}

\begin{abstract}
Berbegal, M., Ortega, A., García-Jiménez, J., and Armengol, J. 2007. Inoculum density-disease development relationship in Verticillium wilt of artichoke caused by Verticillium dahliae. Plant Dis. 91:1131-1136.

The relationship between inoculum density of Verticillium dahliae in soil and disease development was studied in 10 commercial artichoke fields. Inoculum density of $V$. dahliae varied between 2.2 and 34.2 microsclerotia $(\mathrm{ms}) \mathrm{g}^{-1}$ of soil near planting. Artichoke plants were monitored for disease at the beginning and the end of each growing season. There was a significant correlation, which was best described by negative exponential models, between inoculum density and disease incidence, symptom severity, and recovery of the pathogen from the plants. Inoculum densities ranging from 5 to $9 \mathrm{~ms} \mathrm{~g}^{-1}$ of soil were associated with a mean percentage of infected plants of about $50 \%$. Additionally, three fields were monitored in two consecutive growing seasons to evaluate the population dynamics of $V$. dahliae microsclerotia in soil and disease development. Numbers of microsclerotia per gram of soil decreased significantly by the end of the first growing season but slightly increased at the end of the second growing season. In these fields, symptom severity was greatest during the second growing season when high percentages of infected plants also were recorded.
\end{abstract}

Additional keywords: Cynara cardunculus L. var. scolymus

Verticillium dahliae Kleb., a soilborne fungus distributed worldwide, colonizes the vascular tissues of plants, causing wilt in many economically important crops $(3,5,23,32,33,39)$. The pathogen survives by means of microsclerotia in soil for more than 14 years and causes monocyclic diseases $(25,36,44)$. Therefore, inoculum density of the pathogen in field soils at planting plays a critical role in the epidemiology of Verticillium wilt diseases $(23,35,45)$.

Verticillium wilt of artichoke (Cynara cardunculus L. var. scolymus (L.) Fiori) caused by $V$. dahliae first was reported in Italy in 1928 and, since then, has been reported in France (8), Chile (17), and California (6). In recent years, important yield reductions have been observed in artichoke production areas in Italy $(9,10,12)$ and Greece $(41)$.

In Spain, Verticillium wilt of artichoke first was reported in 1984 and now is one of the most important diseases of the crop (40). Recently, infections by $V$. dahliae were found to be widespread in artichoke-

\section{Corresponding author: M. Berbegal \\ E-mail: mobermar@etsia.upv.es}

Accepted for publication 2 April 2007.

doi:10.1094/PDIS-91-9-1131

(C) 2007 The American Phytopathological Society growing areas throughout the Comunidad Valenciana Region in Eastern Spain, a region where 18,400 ha of artichoke are grown annually (1). Artichoke wilt was found in $80.9 \%$ of the sampled fields, with a mean disease incidence of $53.8 \%$ (1). Artichoke is a perennial crop that usually is grown for 2 years; however, the extent of the damage caused by $V$. dahliae has forced many growers to abandon the second growing season when symptoms of the disease become more severe.

Fungicide treatments and soil fumigants cannot successfully control this disease, and artichoke cultivars with resistance to $V$. dahliae are not commercially available $(11,19)$. The long survival of $V$. dahliae microsclerotia in soil and the broad host range of $V$. dahliae are limiting factors for the effectiveness of crop rotations as a control strategy of Verticillium wilt in many crops (30). Although long rotations with resistant or immune crops can reduce the amount of microsclerotia in soil, shortterm rotations do not result in significant reductions of viable microsclerotia (45). Consequently, quantitative information about the inoculum density in soil and its relationship with Verticillium wilt development would be useful for assessing the efficacy of control strategies. It also is essential for disease risk predictions based on the preplanting assessment of initial inoculum (23).
In general, the incidence of Verticillium wilts in herbaceous hosts is proportional to the pathogen inoculum density expressed as the number of viable microsclerotia per gram of soil; however, considerable variation occurs, with such a relationship depending upon crops and cultivars $(21,28,30,35)$. Furthermore, the threshold inoculum density for Verticillium wilt in soil required to cause wilt seems to be crop dependent (45). Nevertheless, it often has been observed that similar amounts of inoculum did not always induce the same amount of infection (2). A lack of correlation between incidence of infection and soil inoculum density has been observed in cotton $(3,14,22)$ and other crops, such as potato $(13,22)$. However, Pullman and DeVay (36) concluded that the incidence of Verticillium wilt in cotton (resulting in plant stunting, foliar symptoms, and yield loss) could be predicted throughout a growing season based on the assessment of the inoculum density at the time of planting. More recently, Paplomatas et al. (35) found that yield responses of cotton crops were dependent on the inoculum density of the pathogen as well as on the disease tolerance of cultivars. Similarly, results from Harris and Yang (23) in strawberry could be used to estimate a critical inoculum density above which disease incidence in a particular cultivar would likely be high enough to justify control measures.

The range of inoculum density of $V$. dahliae in soil epidemiologically significant in wilt disease is known for cauliflower (45), cotton (35), eggplant (15), horseradish (30), potato (33), strawberry (23), and tomato (21). However, only preliminary information was available for artichoke (1).

The objectives of this study were to (i) determine relationships between inoculum density of $V$. dahliae in soil at planting and Verticillium wilt development and (ii) study the population dynamics of $V$. dahliae microsclerotia in soil and the progression of disease incidence, symptom severity, and recovery of the fungus from artichoke plants over two consecutive growing seasons.

\section{MATERIALS AND METHODS}

Field surveys. Ten commercial artichoke fields ( 0.5 to 1 ha, and designated 1 through 10) with a known history of Verti- 
cillium wilt were selected throughout the main production areas located in the Alicante, Castellón, and Valencia provinces of the Comunidad Valenciana Region in 2003, 2004, and 2005 (Table 1). All these fields were planted with stumps (basal stem pieces with attached root sections) of cv. Blanca de Tudela free from the disease because most of artichoke production in Spain is based on the use of this cultivar, which is propagated vegetatively.
Seven of the fields (fields 1 through 3 and 7 through 10) were planted with artichoke for only one growing season, from August of one year through May of the next one, because of the severity of Verticillium wilt. Inoculum density in the 10 fields was determined once, in October, whereas disease incidence, symptom severity, and recovery of the fungus were determined twice, in October and May.

Table 1. Inoculum density (ID) of Verticillium dahliae, disease incidence (DI), percentage of pathogen isolation (PI) and symptom severity (SS) in 10 commercial artichoke fields surveyed in the Comunidad Valenciana during one growing season ${ }^{\mathrm{w}}$

\begin{tabular}{cllccrr}
\hline Field & Province & Sampling $^{\mathbf{x}}$ & ID $_{\left(\mathbf{m s ~ g}^{\mathbf{- 1}}\right)^{\mathbf{y}}}$ & DI $(\boldsymbol{\%})^{\mathbf{z}}$ & \multicolumn{1}{c}{ PI $(\boldsymbol{\%})^{\mathbf{z}}$} & \multicolumn{1}{c}{ SS $(\boldsymbol{\%})^{\mathbf{z}}$} \\
\hline 1 & Castellón & October 2003 & $34.2 \pm 3.9$ & $97.5 \pm 1.7 \mathrm{a}$ & $61.8 \pm 2.9 \mathrm{a}$ & $43.7 \pm 3.9 \mathrm{a}$ \\
& $\ldots$ & May 2004 & $\ldots$ & $98.8 \pm 1.2 \mathrm{a}$ & $10.5 \pm 2.1 \mathrm{~b}$ & $45.7 \pm 4.1 \mathrm{a}$ \\
2 & Castellón & October 2003 & $9.4 \pm 1.7$ & $52.9 \pm 6.3 \mathrm{a}$ & $20.1 \pm 3.8 \mathrm{a}$ & $14.8 \pm 2.5 \mathrm{a}$ \\
& $\ldots$ & May 2004 & $\ldots$ & $76.1 \pm 4.4 \mathrm{~b}$ & $5.4 \pm 2.3 \mathrm{~b}$ & $40.7 \pm 5.7 \mathrm{~b}$ \\
3 & Castellón & October 2003 & $26.2 \pm 3.5$ & $76.6 \pm 6.0 \mathrm{a}$ & $26.3 \pm 3.4 \mathrm{a}$ & $17.2 \pm 3.3 \mathrm{a}$ \\
& $\ldots$ & May 2004 & $\ldots$ & $87.9 \pm 3.6 \mathrm{a}$ & $14.1 \pm 3.8 \mathrm{~b}$ & $35.2 \pm 4.8 \mathrm{~b}$ \\
4 & Valencia & October 2003 & $8.9 \pm 1.6$ & $12.5 \pm 4.1 \mathrm{a}$ & $1.5 \pm 0.6 \mathrm{a}$ & $8.9 \pm 1.9 \mathrm{a}$ \\
& $\ldots$ & May 2004 & $\ldots$ & $28.7 \pm 4.7 \mathrm{~b}$ & $0.2 \pm 0.1 \mathrm{a}$ & $34.7 \pm 3.9 \mathrm{~b}$ \\
5 & Alicante & October 2003 & $9.3 \pm 1.5$ & $55.0 \pm 8.1 \mathrm{a}$ & $27.9 \pm 5.0 \mathrm{a}$ & $29.1 \pm 3.2 \mathrm{a}$ \\
& $\ldots$ & May 2004 & $\ldots$ & $69.1 \pm 7.6 \mathrm{a}$ & $5.0 \pm 1.5 \mathrm{~b}$ & $42.2 \pm 4.9 \mathrm{~b}$ \\
6 & Alicante & October 2003 & $2.9 \pm 0.6$ & $6.3 \pm 2.5 \mathrm{a}$ & $0.6 \pm 0.3 \mathrm{a}$ & $16.3 \pm 2.8 \mathrm{a}$ \\
& $\ldots$ & May 2004 & $\ldots$ & $11.3 \pm 3.8 \mathrm{a}$ & $0.1 \pm 0.1 \mathrm{~b}$ & $16.8 \pm 2.9 \mathrm{a}$ \\
7 & Castellón & October 2004 & $5.4 \pm 2.5$ & $69.1 \pm 6.2 \mathrm{a}$ & $31.4 \pm 3.9 \mathrm{a}$ & $19.7 \pm 3.3 \mathrm{a}$ \\
& $\ldots$ & May 2005 & $\ldots$ & $77.9 \pm 5.9 \mathrm{a}$ & $4.0 \pm 1.1 \mathrm{~b}$ & $26.6 \pm 4.2 \mathrm{a}$ \\
8 & Castellón & October 2004 & $2.7 \pm 1.1$ & $62.0 \pm 6.5 \mathrm{a}$ & $28.7 \pm 4.1 \mathrm{a}$ & $11.4 \pm 2.8 \mathrm{a}$ \\
& $\ldots$ & May 2005 & $\ldots$ & $68.6 \pm 5.7 \mathrm{a}$ & $6.5 \pm 1.5 \mathrm{~b}$ & $43.1 \pm 2.9 \mathrm{~b}$ \\
9 & Castellón & October 2004 & $5.4 \pm 0.8$ & $34.5 \pm 6.2 \mathrm{a}$ & $10.2 \pm 3.1 \mathrm{a}$ & $11.2 \pm 1.6 \mathrm{a}$ \\
& $\ldots$ & May 2005 & $\ldots$ & $61.2 \pm 6.3 \mathrm{~b}$ & $2.6 \pm 1.1 \mathrm{~b}$ & $59.2 \pm 4.4 \mathrm{~b}$ \\
10 & Alicante & October 2004 & $2.2 \pm 0.5$ & $18.3 \pm 5.2 \mathrm{a}$ & $3.6 \pm 1.2 \mathrm{a}$ & $7.0 \pm 2.1 \mathrm{a}$ \\
& $\ldots$ & May 2005 & $\ldots$ & $36.5 \pm 6.4 \mathrm{~b}$ & $2.4 \pm 0.9 \mathrm{a}$ & $6.7 \pm 2.9 \mathrm{a}$ \\
\hline
\end{tabular}

${ }^{\text {w}}$ Data are presented \pm the standard error of the mean. For each field, means followed by the same letter within columns are not significantly different according to a least significant difference test $(P$ $\leq 0.05$ ).

${ }^{x}$ Each field was surveyed in an "W" pattern and five sites of approximately 3 by $3 \mathrm{~m}^{2}$ were selected along each of the four diagonal lines, 20 sample areas in total. Soil samples were taken in October and plant samples were taken in October and May, at the beginning and the end, respectively, of one growing season.

y Soil samples representing the 20 sample areas were analyzed for ID of V. dahliae using the modified Anderson sampler technique. For each of the 10 surveyed fields, the ID (microsclerotia per gram of soil $\left[\mathrm{ms} \mathrm{g}^{-1}\right]$ ) was calculated as the mean of values obtained from the 20 sites assessed.

${ }^{\mathrm{z}}$ Four plants per sample area were evaluated to obtain mean values of DI, PI, and SS. For each of the 10 surveyed fields and sampling time, the DI (\%), PI (\%), and SS (\%) were calculated as the mean of values obtained from the 20 sites assessed.

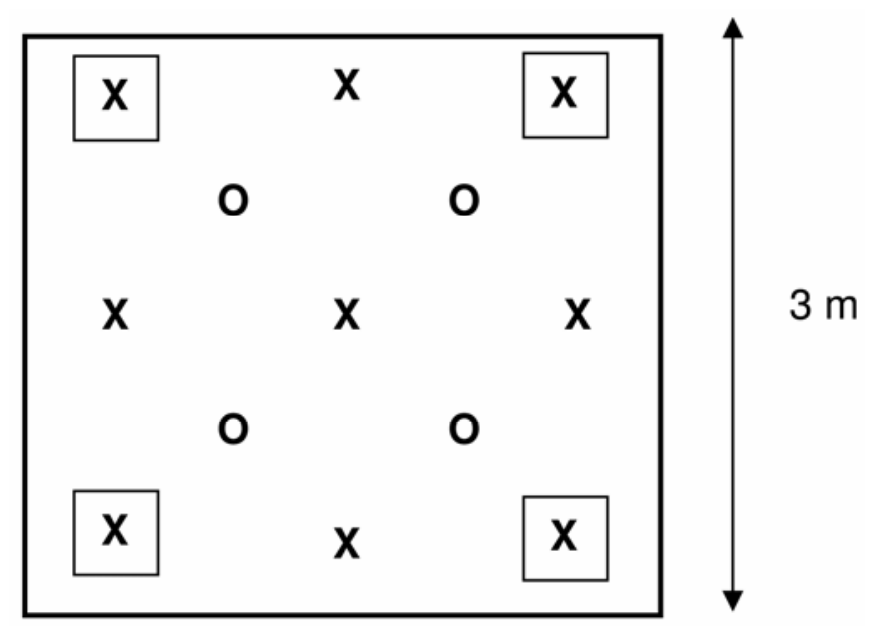

Fig. 1. Scheme of one of the 20 sample areas surveyed in each field. Artichoke plants are represented by crosses and locations of soil cores by circles. Crosses in a box represent artichoke plants selected for visual evaluation of the symptoms and isolations.

Fields 4, 5, and 6 were grown for two growing seasons. In these fields, disease intensity and inoculum density were determined at the beginning and the end of each of the growing seasons (October and May, respectively).

Twenty sites ( 3 by $3 \mathrm{~m}$ ) were marked per field in a "W" pattern. In each of these 20 sample areas, which included nine plants (Fig. 1), soil was sampled and disease in plants assessed. The following parameters were studied in each sample area.

Inoculum density. Four soil cores were collected to a depth of $10 \mathrm{~cm}$ from each sample area and bulked into a single soil sample. Soil samples were air dried for 4 weeks. After the dried soil was homogenized, $10 \mathrm{~g}$ of soil from each sample was mixed with $2.5 \mathrm{ml}$ of $0.75 \mathrm{~g}$ of DLmethionine in $100 \mathrm{ml}$ of distilled water in a snap-cap vial and incubated at $30^{\circ} \mathrm{C}$ for 1 week to break the dormancy of microsclerotia. Thereafter, vials were opened and the soil was allowed to dry for 5 days at room temperature. The dried soil samples were homogenized further and $100 \mathrm{mg}$ was spread onto NP-10 medium (29) in petri plates using the modified Anderson air sampler method (7). Five plates with 100 mg per plate were used for each soil sample. Plates were incubated in the dark at $23^{\circ} \mathrm{C}$ for 3 weeks. After incubation, plates were washed with tap water to remove particles and aerial mycelia from the agar surface and facilitate the identification of colonies of $V$. dahliae under the stereomicroscope. Colonies of $V$. dahliae were identified based on morphology of microsclerotia formed into the agar, their distribution within the medium, and the absence of dark hyphae or dark mycelium (20). The inoculum density (ID) in a sample was estimated as number of microsclerotia per gram of dry soil, and it was recorded for each sample area studied.

Symptom severity. Severity of plant symptoms was assessed on a 0-to-100\% rating scale adapted from Cirulli et al. (11), with six levels that took into account foliar symptoms (yellowing and wilting) and plant stunting $(0=$ no symptoms, $10 \%=1$ to $9 \%$ of affected leaf surface and very slight stunting, $20 \%=10$ to $24 \%$ of affected leaf surface and very slight to moderate stunting, $60 \%=25$ to $50 \%$ of affected leaf surface and very slight to severe stunting, $80 \%=$ more than $50 \%$ of affected leaf surface and very slight to severe stunting, and $100 \%=$ dead plant). Symptoms were evaluated in four artichoke plants per sample area (Fig. 1) to obtain a mean value of severity of symptoms (SS).

Disease incidence and recovery of pathogen. Four basal leaves from each of the four plants assessed for disease symptoms were sampled from each area and examined in the laboratory. Leaves were washed, surface sterilized for $1 \mathrm{~min}$ in sodium hypochlorite solution $(1.5 \%$ active 
chlorine), and rinsed twice with sterile water. Subsequently, four small internal fragments of vascular tissue from each leaf were plated onto potato dextrose agar supplemented with streptomycin sulfate (PDAS) at $0.5 \mathrm{mg} \mathrm{m}^{-1}$ and incubated at $25^{\circ} \mathrm{C}$. The colonies that developed on the plates were examined periodically and $V$. dahliae was identified based on the presence of microsclerotia and conidiophore morphology. Values of disease incidence (DI) corresponding to each sample area were obtained as the percentage of infected plants. A plant was considered infected when $V$. dahliae was recovered at least once. Values of percentage of isolations (PI) from the different sample areas were estimated as the percentage of positive isolations from the 64 total isolations made per sample area.

Data analyses. For each field in the study, the ID, SS, DI, and PI were calculated as the mean of values obtained from the 20 sites assessed per field. Therefore, the mean value for each of the studied parameters per field was used in the analysis. The relationships between ID at planting and SS, DI, and PI in the beginning (October) and the end (May) of one growing season were determined by nonlinear regression analysis using Statgraphics Plus 5.1 software (Manugistics Inc., Rockville, $\mathrm{MD})$. Analyses of variance were performed on data obtained from fields studied during one and two consecutive growing seasons and means were compared by the least significant difference test $(P \leq$ 0.05 ) using the same software.

\section{RESULTS}

Influence of ID on DI, PI, and SS. The average number of propagules of $\mathrm{V}$. dahliae per gram of soil, and mean values of DI, percentage of PI, and SS in each field of the study for the two sampling times in a growing season are shown in Table 1. At the beginning of the growing season, the ID of $V$. dahliae in soil varied between 2.2 and 34.2 microsclerotia $(\mathrm{ms}) \mathrm{g}^{-1}$ of soil, whereas DI ranged from 6.3 to $97.5 \%$ in October and 11.3 to $98.8 \%$ in May at the end of the growing season. Mean values of PI and SS also were highly variable in October, ranging from 0.6 to $61.8 \%$ and from 7 to $43.7 \%$, respectively. In May, PI ranged from 0.1 to $14.1 \%$ whereas SS varied between 6.7 and $59.2 \%$.

ID in October was plotted against mean values of DI, PI, and SS obtained for the 10 fields assessed in October and May (Figs. 2 and 3). There was a significant correlation between ID and the variables related with disease development (DI, PI, and SS) and these relationships were best described by a negative exponential model. Plots showed that DI, PI, and SS at the beginning of the growing season in October and at the end of the season in May were closely related to mean ID values in October, with the coefficients of determination ranging from 0.40 to 0.48 and from 0.33 to 0.63 , respectively. However, there was no correlation between DI or PI and SS, indicating that there was no correlation between Verticillium wilt symptoms severity in artichoke and the incidence of the disease in the field.
Population dynamics of $V$. dahliae microsclerotia and progression of DI, recovery of the pathogen from tissue, and SS. Mean values of ID, DI, PI, and SS obtained for fields 4,5 , and 6 in the four sampling times within the two growing seasons are shown in Table 2. ID ranged from 0.6 to $8.9 \mathrm{~ms} \mathrm{~g}^{-1}$ of soil in field 4 , from 0.7 to 9.3 in field 5 , and from 0.1 to 2.9 in field 6 . The highest ID values detected in soil occurred in October at the first growing season. By May, those values had decreased significantly in fields 5 and 6 , and remained at the same level or increased slightly during the second growing season. An exception to that was observed in field 4, where ID decreased significantly in October, at the beginning of the second growing season, but increased again by May.

The percentage of infected plants (DI) increased progressively over time, ranging from 12.5 to $55.7 \%$ in field 4 , from 55 to $92 \%$ in field 5 , and from 6.2 to $32 \%$ in field 6. Significant increases of DI values were observed in all fields in October of the second growing season, at the time that lower ID levels were detected in soil.

In both growing seasons, mean values of PI from plants evaluated per field were lower in spring than in autumn, thus suggesting that seasonality occurred in the isolation of $V$. dahliae from artichoke plants.

In all fields, SS was greatest during the second growing season, when high percentages of infected plants also were recorded.
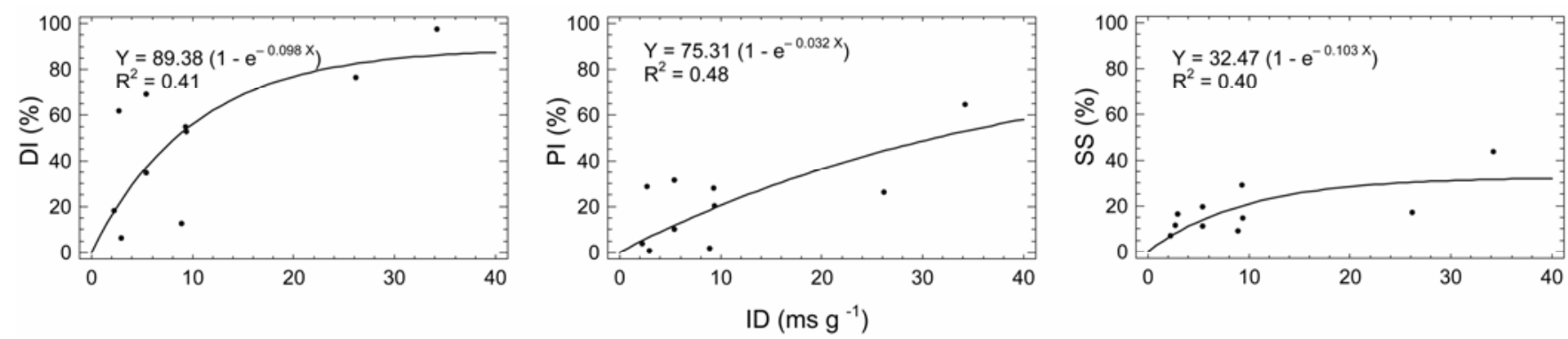

Fig. 2. Negative exponential models to describe the relationships between Verticillium dahliae inoculum density (ID) in soil close to planting time and disease incidence (DI), percentage pathogen isolation (PI), and symptom severity (SS) in autumn, at the beginning of the first growing season. Data points represent mean values corresponding to each field obtained from the 20 individual sample areas assessed.
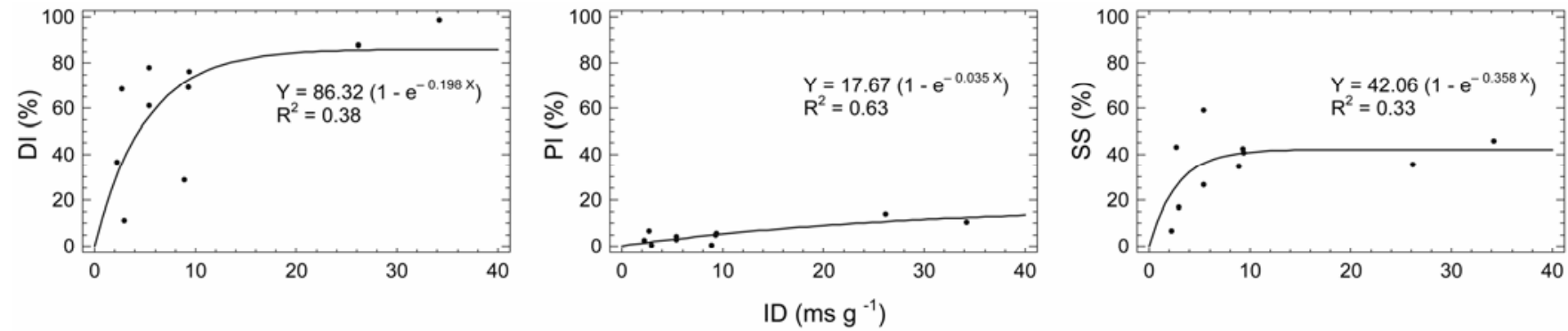

Fig. 3. Negative exponential models to describe the relationships between Verticillium dahliae inoculum density (ID) in soil close to planting time and disease incidence (DI), percentage pathogen isolation (PI), and symptom severity (SS) in spring, at the end of the first growing season. Data points represent mean values corresponding to each field obtained from the 20 individual sample areas assessed. 


\section{DISCUSSION}

This is the first study that characterizes the relationships between the ID of $V$. dahliae in soil and development of Verticillium wilt of artichoke. Information about these relationships is essential for disease risk assessment and development of disease management options. The perennial growth habit of artichoke also allowed the study of the dynamics of microsclerotia population in soil and progression of disease during two growing seasons.

The relationship of $V$. dahliae microsclerotia density in soil and Verticillium wilts vary with crops. For example, in cotton, field inoculum densities of $19 \mathrm{~ms} \mathrm{~g}^{-1}$ can result in the infection of $50 \%$ of plants (36). In strawberry fields, only $0.3 \mathrm{~ms} \mathrm{~g}^{-1}$ of the plants (23). Xiao and Subbarao (45) concluded that cauliflower has relatively little tolerance to $V$. dahliae because even 1 $\mathrm{ms}^{-1}$ of soil had the potential to infect $5 \%$ of plants in a field. In the present study, ID of only $1 \mathrm{~ms} \mathrm{~g}^{-1}$ of soil in artichoke fields in the Comunidad Valenciana Region resulted in disease in about $15 \%$ of the plants by the end of the first growing season. Moreover, a small increase in the ID to about $3 \mathrm{~ms} \mathrm{~g}^{-1}$ resulted in about $40 \%$ of infected artichoke plants, an incidence high enough to reduce yield (1). Thus, we conclude that low levels of $V$. dahliae ID in soil could become an important limiting factor for crop profitability. In artichoke fields at the Comunidad Valenciana Region, ID in soil ranging from 5 to $9 \mathrm{~ms} \mathrm{~g}^{-1}$ of soil were associated with a mean percentage of infected plants of about $50 \%$. Therefore, for disease management, it is can result in the infection of more than $5 \%$

desirable to reduce ID in soils as much as possible. Information from this study could help to decide the nature of disease control strategies worth applying, as well as when and how long they should be used, based on the results of preplant analysis of soil samples for the quantification of microsclerotia.

Linear and curvilinear relationships between ID of $V$. dahliae and wilt incidence and severity have been reported for different crops $(2,4,21,23,30,33,35,36,45)$. In the present study, negative exponential models best described the association between ID of $V$. dahliae in soil close to artichoke plantation and DI, PI and SS at the beginning and the end of one growing season. The lack of ID values between 10 and $25 \mathrm{~ms} \mathrm{~g}^{-1}$ could have limited the identification of the response curve. Nevertheless, similar curvilinear ID-DI relationships involving $V$. dahliae have been confirmed by results from field surveys $(30,35,36,45)$. The relatively low coefficients of determination (ranging from 0.33 to 0.66 ) obtained in our study could limit reliability of predictions of DI, PI, and SS in relation to ID of the pathogen in soil. The low correlation between those variables under field conditions reflect the effect of several factors that affect the relationship between the pathogen and their hosts, including cultural practices, soil type, environmental conditions, host resistance, and virulence variation of $V$. dahliae isolates prevailing in the soil $(3,14,22$, 26,30,45). For example, in the United Kingdom, Verticillium wilt of strawberry was found associated mainly with light and sandy soils (23). Cultural practices have strong influence on disease development

Table 2. Inoculum density (ID) of Verticillium dahliae, disease incidence (DI), percentage of pathogen isolation (PI), and symptom severity (SS) in three commercial artichoke fields surveyed in the Comunidad Valenciana during two consecutive growing seasons ${ }^{\mathrm{W}}$

\begin{tabular}{llrrrr}
\hline Field & Sampling $^{\mathbf{x}}$ & ${\text { ID }\left(\mathbf{m s ~ g}^{-\mathbf{1}}\right)^{\mathbf{y}}}$ & DI $(\boldsymbol{\%})^{\mathbf{z}}$ & \multicolumn{1}{c}{ PI $(\%)^{\mathbf{z}}$} & \multicolumn{1}{c}{$\mathbf{S S}(\boldsymbol{\%})^{\mathbf{z}}$} \\
\hline 4 & October 2003 & $8.9 \pm 1.6 \mathrm{a}$ & $12.5 \pm 4.1 \mathrm{a}$ & $1.5 \pm 0.6 \mathrm{a}$ & $8.9 \pm 1.9 \mathrm{a}$ \\
& May 2004 & $5.1 \pm 0.8 \mathrm{a}$ & $28.7 \pm 4.7 \mathrm{~b}$ & $0.2 \pm 0.1 \mathrm{a}$ & $34.7 \pm 3.9 \mathrm{~b}$ \\
& October 2004 & $0.6 \pm 0.3 \mathrm{~b}$ & $50.7 \pm 6.0 \mathrm{c}$ & $4.3 \pm 1.6 \mathrm{~b}$ & $29.6 \pm 5.0 \mathrm{~b}$ \\
5 & May 2005 & $6.6 \pm 2.1 \mathrm{a}$ & $55.7 \pm 6.2 \mathrm{c}$ & $1.1 \pm 0.6 \mathrm{a}$ & $37.7 \pm 4.7 \mathrm{~b}$ \\
& October 2003 & $9.3 \pm 1.5 \mathrm{a}$ & $55.0 \pm 8.1 \mathrm{a}$ & $27.9 \pm 5.0 \mathrm{a}$ & $29.1 \pm 3.2 \mathrm{a}$ \\
& May 2004 & $2.4 \pm 0.5 \mathrm{~b}$ & $69.1 \pm 7.6 \mathrm{a}$ & $5.0 \pm 1.5 \mathrm{~b}$ & $42.2 \pm 4.9 \mathrm{~b}$ \\
& October 2004 & $0.7 \pm 0.4 \mathrm{~b}$ & $91.1 \pm 3.6 \mathrm{~b}$ & $40.5 \pm 7.8 \mathrm{a}$ & $67.7 \pm 4.4 \mathrm{c}$ \\
& May 2005 & $2.5 \pm 0.6 \mathrm{~b}$ & $92.0 \pm 5.3 \mathrm{~b}$ & $8.5 \pm 3.5 \mathrm{~b}$ & $77.7 \pm 4.8 \mathrm{c}$ \\
6 & October 2003 & $2.9 \pm 0.6 \mathrm{a}$ & $6.3 \pm 2.5 \mathrm{a}$ & $0.6 \pm 0.3 \mathrm{a}$ & $16.3 \pm 2.8 \mathrm{a}$ \\
& May 2004 & $0.1 \pm 0.1 \mathrm{~b}$ & $11.3 \pm 3.8 \mathrm{a}$ & $0.1 \pm 0.1 \mathrm{~b}$ & $16.8 \pm 2.9 \mathrm{a}$ \\
& October 2004 & $0.1 \pm 0.1 \mathrm{~b}$ & $25.0 \pm 5.1 \mathrm{~b}$ & $0 \pm 0 \mathrm{~b}$ & $16.3 \pm 2.8 \mathrm{a}$ \\
& May 2005 & $1.3 \pm 0.6 \mathrm{~b}$ & $32.0 \pm 5.4 \mathrm{~b}$ & $0 \pm 0 \mathrm{~b}$ & $38.4 \pm 5.2 \mathrm{~b}$ \\
\hline
\end{tabular}

${ }^{\mathrm{w}}$ Data are presented \pm the standard error of the mean. For each field, means followed by the same letter within columns are not significantly different according to a least significant difference test $(P$ $\leq 0.05$ ).

"Each field was surveyed in an "W" pattern and five sites of approximately 3 by $3 \mathrm{~m}^{2}$ were selected along each of the four diagonal lines, 20 sample areas in total. Samples were taken in October and May, at the beginning and the end, respectively, of two consecutive growing seasons.

y Soil samples representing the 20 sample areas were analyzed for ID of V. dahliae using the modified Anderson sampler technique. For each of the surveyed fields and sampling time, the ID (microsclerotia per gram of soil $\left[\mathrm{ms} \mathrm{g}^{-1}\right]$ ) was calculated as the mean of values obtained from the 20 sites assessed.

${ }^{\mathrm{z}}$ Four plants per sample area were evaluated to obtain mean values of DI, PI, and SS. For each of the surveyed fields and sampling time, the DI (\%), PI (\%), and SS (\%) were calculated as the mean of values obtained from the 20 sites assessed. on potato and cauliflower $(33,45)$. In cotton, the role of the ID on vascular infections or development of foliar symptoms changes with the cultivar tolerance and different pathotypes of $V$. dahliae $(3,35)$. The ID in a field obtained by existing quantitative soil assay procedures for $V$. dahliae can be different from the real inoculum potential, considering that mixtures of pathogenic strains of $V$. dahliae with varying virulence can be present in the soil (27). Therefore, estimating the threat deriving from Verticillium soil infestation is difficult on the basis of a quantitative assessment of soil ID alone and it is necessary to have information about the predominant virulence type or vegetative compatibility groups (VCGs) present (46). Recent studies have revealed a limited VCG diversity in the population of $V$. dahliae from artichoke in the Comunidad Valenciana Region, where VCG2 prevailed among the four VCGs (VCG1A, VCG2A, VCG2B, and VCG4B) identified in this area, with VCG2B being the predominant subgroup (26).

In this study, we observed a clear trend in the results obtained from the fields evaluated in only 1 year. In general, the DI and SS increased significantly in May compared with those in October, whereas PI from plants were significantly lower in May than in October. This trend was confirmed by results obtained in two consecutive years. Values of DI and SS increased progressively and means at the end of the second growing season were significantly higher compared with those in autumn, close to planting time. These results clearly agree with the real situation in commercial fields, where it is difficult to find biennial crops due to important yield reductions caused by Verticillium wilt that usually force growers to abandon the second growing season.

Frequency of $V$. dahliae isolations from plants were higher in autumn than in spring in all fields of the study, suggesting a clear influence of seasons and, perhaps, temperature (42). This fact was observed earlier in artichoke (34) and in other crops, such as olive $(31,42)$, maple (37), and potato (33). Seasonality also may be influenced by anatomical and physiological changes in the plants (37).

Little is known about the dynamics of $V$. dahliae microsclerotia population in the soil of commercial fields. Wheeler et al. (43) evaluated the ID in spring and autumn of the same year in potato fields located in Ohio. More microsclerotia were recovered in autumn, the end of the growing season, than in spring. Evans et al. (16) studied the seasonal fluctuation in numbers of Verticillium microsclerotia in cotton field soils. In that study, ID decreased throughout the growing season but increased at harvest time with the release of microsclerotia from damaged tissues of infected plants into soil. In our 
study, numbers of microsclerotia in soil decreased significantly by the end of the first growing season (spring) and slightly increased at the end of the second growing season. Several factors, such as microbial antagonism, could be involved in the quick loss in the number of viable microsclerotia from soil (16). Microsclerotia would germinate near the plants roots, leading to a decline in the population of viable propagules in soil until the incorporation of new inoculum from infected tissues at the end of the crop. In our study, high percentages of infected plants and SS were recorded in fields with low inoculum densities, due probably to the germination of the microsclerotia and, consequently, infection of the plants.

All factors that may influence Verticillium wilt potential, as well as nonuniform distribution of the pathogen in soil $(24,38)$ and limitations of current soil assay methods (18), contribute to making it difficult to use ID to reliably predict Verticillium wilt incidence $(22,23)$. However, the information obtained in this study could provide a basis for disease risk assessment and development of control strategies of Verticillium wilt of artichoke. Results from this study are useful for determining critical ID at planting, above which disease incidence is likely to justify control measures in artichoke fields.

\section{ACKNOWLEDGMENTS}

This research was supported by the projects AGL2000-1444 (Comisión Interministerial de Ciencia y Tecnología) and GV-CAPA00-12 (Consellería de Agricultura, Pesca y Alimentación de la Generalitat Valenciana). Mónica Berbegal was supported by a grant from Ministerio de Educación y Ciencia (AP2002-3818). We thank M. A. Royuela and A. Ramírez for their assistance in performing the experiments and R. M. Jiménez-Díaz for helpful comments on the manuscript prior to submission.

\section{LITERATURE CITED}

1. Armengol, J., Berbegal, M., Giménez-Jaime, A., Romero, S., Beltrán, R., Vicent, A., Ortega, A., and García-Jiménez, J. 2005. Incidence of Verticillium wilt of artichoke in Eastern Spain and role of inoculum sources on crop infection. Phytoparasitica 33(4):397-405

2. Ashworth, L. J., Huisman, O. C., Harper, D. M., Stromberg, L. K., and Bassett, D. M. 1979. Verticillium wilt disease of cotton: influence of inoculum density in the field. Phytopathology 69:483-489.

3. Bejarano-Alcázar, J., Melero-Vara, J. M., Blanco-López, M. A., and Jiménez-Díaz, R. M. 1995. Influence of inoculum density of defoliating and nondefoliating pathotypes of Verticillium dahliae on epidemics of Verticillium wilt of cotton in southern Spain. Phytopathology 85:1474-1481.

4. Bhat, R. G., Smith, R. F., Koike, S. T., Wu, B. M., and Subbarao, K. V. 2003. Characterization of Verticillium dahliae isolates and wilt epidemics of pepper. Plant Dis. 87:789-797.

5. Bhat, R. G., and Subbarao, K. V. 1999. Host range specificity in Verticillium dahliae. Phytopathology 89(12):1218-1225.

6. Bhat, R. G., Subbarao, K. V., and Bari, M. A. 1999. First report of Verticillium dahliae causing artichoke wilt in California. Plant Dis.
83:782.

7. Butterfield, E. J., and DeVay, J. E. 1977. Reassessment of soil assays for Verticillium dahliae. Phytopathology 67:1073-1078.

8. Chambonnet, D., Pochard, E., and Vigoroux, A. 1967. La verticilliose de l'artichaut dans le sud-est de la France. Phytopathol. Mediterr. 6:95-99.

9. Ciccarese, F., Schiavone, D., and Bottalico, A. 2000. Survey on Verticillium-wilt of artichoke in Apulia and pathogenic variations among isolates of Verticillium dahliae. Acta Hortic. 681:617-623.

10. Cirulli, M., Amenduni, M., D'amico, M., and Colella, C. 2000. Verticillium wilt of artichoke caused by Verticillium dahliae Kleb. Acta Hortic. 681:603-606.

11. Cirulli, M., Ciccarese, F., and Amenduni, M. 1994. Evaluation of Italian clones of artichoke for resistance to Verticillium dahliae. Plant Dis. 78:680-682.

12. Cirulli, M., Ciccarese, F., and Frisullo, S. 1984. L'avvizzimento del carciofo da Verticillium dahliae Kleb. in Italia meridionale. Inf. Agrario 40(30):52-54.

13. Davis, J. R., and Everson, D. O. 1986. Relation of Verticillium dahliae in soil and potato tissue, irrigation method, and N-fertility to Verticillium wilt of potato. Phytopathology 76:730736.

14. DeVay, J. E., Forrester, Linda L., Garber, R. H., and Butterfield, E. J. 1974. Characteristics and concentration of propagules of Verticillium dahliae in air-dried field soils in relation to the prevalence of Verticillium wilt in cotton. Phytopathology 64:22-29.

15. Evans, G., and McKeen, C. D. 1975. Influence of crops on numbers of microsclerotia of Verticillium dahliae in soils and the development of wilt in southwestern Ontario. Can. J. Plant Sci. 55:827-834.

16. Evans, G., Wilhelm, S., and Snyder, W. C. 1967. Quantitative studies by plate counts of propagules of the Verticillium wilt fungus in cotton fields soils. Phytopathology 57:12501255.

17. Fernández, M. C., and Tobar, C. G. 1989. Identificación de Verticillium dahliae Kleb. en alcachofas Cynara scolymus. Agric. Tec. (Santiago) 49:161-163.

18. Goud, J. C., and Termorshuizen, A. J. 2003. Quality of methods to quantify microsclerotia of Verticillium dahliae in soil. Eur. J. Plant Pathol. 109:523-534.

19. Goud, J. C., Termorshuizen, A. J., Blok, W. J., and van Bruggen, A. H. C. 2004. Long-term effect of biological soil disinfestation on Verticillium wilt. Plant Dis. 88:688-694.

20. Goud, J. C., Termorshuizen, A. J., and Gams, W. 2003. Morphology of Verticillium dahliae and $V$. tricorpus on semi-selective media used for the detection of $V$. dahliae in soil. Mycol. Res. 107(7):822-830.

21. Grogan, R. G., Ioannou, N., Schneider, R. W., Sall, M. A., and Kimble, K. A. 1979. Verticillium wilt on resistant tomato cultivars in California: virulence of isolates from plants and soil and relationship of inoculum density to disease incidence. Phytopathology 69:11761180.

22. Harrington, M. A., and Dobinson, K. F. 2000. Influences of cropping practices on Verticillium dahliae populations in commercial processing tomato fields in Ontario. Phytopathology 90:1011-1017.

23. Harris, D. C., and Yang, J. R. 1996. The relationship between the amount of Verticillium dahliae in soil and the incidence of strawberry wilt as a basis for disease risk prediction. Plant Pathol. 45:106-114.

24. Harris, D. C., Yang, J. R., and Ridout, M. S. 1993. The detection and estimation of Verticillium dahliae in naturally infested soils. Plant Pathol. 42:238-250.
25. Hiemstra, J. A. 1998. Some general features of Verticillium wilts in trees. Pages 5-11 in: A Compendium of Verticillium wilts in Tree Species. J. A. Hiemstra and D. C. Harris, eds CPRO-DLO, Wageningen, The Netherlands.

26. Jiménez-Díaz, R. M., Mercado-Blanco, J., Olivares-García, C., Collado-Romero, M., Bejarano-Alcázar, J., Rodríguez-Jurado, D., Giménez-Jaime, A., García-Jiménez, J., and Armengol, J. 2006. Genetic and virulence diversity in Verticillium dahliae populations infecting artichoke in eastern-central Spain. Phytopathology 96:288-298.

27. Joaquim, T. R., and Rowe, R. C. 1991. Vegetative compatibility and virulence of strains of Verticillium dahliae from soil and potato plants. Phytopathology 81:552-558.

28. Jordan, V. W. 1974. Verticillium wilt of strawberry: cultivar reaction and effect on runner health and production. Plant Pathol. 23:8-13.

29. Kabir, Z., Bhat, R. G., and Subbarao, K. V. 2004. Comparison of media for recovery of Verticillium dahliae from soil. Plant Dis. 88(1):49-55.

30. Khan, N., Atibalentja, N., and Eastburn, D. M. 2000. Influence of inoculum density of Verticillium dahliae on root discoloration of horseradish. Plant Dis. 84:304-315.

31. Levin, A. G., Lavee, S., and Tsor, L. 2003. Epidemiology of Verticillium dahliae on olive (cv. Picual) and its effect on yield under saline conditions. Plant Pathol. 52:212-218.

32. Melouk, H. A. 1993. Methods for Research on Soilborne Phytopathogenic Fungi. J. D. M. L. L. Singleton and C. M. Rush, eds. The American Phytopathological Society Press, St. Paul, MN.

33. Nicot, P. C., and Rouse, D. I. 1987. Relationship between soil inoculum density of Verticillium dahliae and systemic colonization of potato stems in commercial fields over time. Phytopathology 77:1346-1355.

34. Ortega, A., Rubio, R., García-Molina, L. Vicent, A., Beltrán, R., Armengol, J., and García-Jiménez, J. 2004. Seasonal variation of Verticillium dahliae isolation from artichoke. Acta Hortic. 660:517-522.

35. Paplomatas, E. J., Basse, D. M., Broome, J. C., and DeVay, J. E. 1992. Incidence of Verticillium wilt and yield losses of cotton cultivars (Gossypium hirsutum) based on soil inoculum density of Verticillium dahliae. Phytopathology 82:1417-1420.

36. Pullman, G. S., and DeVay, J. E. 1982. Epidemiology of Verticillium wilt of cotton: a relationship between inoculum density and disease progression. Phytopathology 72:549-554.

37. Schreiber, L. R., and Mayer J. S. 1992. Seasonal variations in susceptibility and in internal inoculum densities in maple species inoculated with Verticillium dahliae. Plant Dis. 76:184 187.

38. Smith, V. L., and Rowe, R. C. 1984. Characteristics and distribution of propagules of Verticillium dahliae in Ohio potato fields soils and assessment of two assay methods. Phytopathology 74:553-556.

39. Subbarao, K. V., Chassot, A., Gordon, T. R. Hubbard, J. C., Bonello, P., Mllin, R., Okamoto, D., Davis, R. M., and Koike, S. T. 1995. Genetic relationships and cross pathogenicities of Verticillium dahliae isolates from cauliflower and other crops. Phytopathology 85:1105-1112.

40. Tello, J. C. 1984. Enfermedades criptogámicas en hortalizas. Comunicaciones I. N. I. A. Serie: Proteción Vegetal 22. Madrid, Spain

41. Tjamos, E. C., and Paplomatas, E. J. 1988 Long-term effect of soil solarization in controlling Verticillium wilt of globe artichokes in Greece. Plant Pathol. 37:507-515.

42. Tosi, L., and Zazzerini, A. 1998. Estudio epidemiológico sobre la verticilosis del olivo en la Italia central. Olivae 71:50-55. 
43. Wheeler, T. A., Madden, L. V., Rowe, R. C., and Riedel, R. M. 2000. Effects of quadrat size and time of year for sampling of Verticillium dahliae and lesion nematodes in potato fields. Plant Dis. 84:961-966.

44. Wilhelm, S. 1955. Longevity of the Verticil- lium wilt fungus in the laboratory and field. Phytopathology 45:180-181.

45. Xiao, C. L., and Subbarao, K. V. 1998. Relationship between Verticillium dahliae inoculum density and wilt incidence, severity, and growth of cauliflower. Phytopathology
88(10):1108-1115

46. Zeise, K., and von Tiedemann, A. 2002. Host specialization among vegetative compatibility groups of Verticillium dahliae in relation to Verticillium longisporum. J. Phytopathol. 150:112-119. 